PNL-7355

UC-602

$2 F$

\title{
Initial Tests on In Situ Vitrification Using Electrode Feeding Techniques
}

R. K. Farnsworth

K. H. Oma

C. E. Bigelow

May 1990

Prepared for the U.S. Department of Energy under Contract DE-AC06-76RLO 1830

Pacific Northwest Laboratory Operated for the U.S. Department of Energy by Battelle Memorial Institute 


\title{
DISCLAIMER
}

This report was prepared as an account of work sponsored by an agency of the United States Government. Neither the United States Government nor any agency thereof, nor Battelle Memorial Institute, nor any of their employees, makes any warranty, expressed or implied, or assumes any legal liability or responsibility for the accuracy, completeness, or usefulness of any information, apparatus, product, or process disclosed, or represents that its use would not infringe privately owned rights. Reference herein to any specific commercial product, process, or service by trade name, trademark, manufacturer, or otherwise, does not necessarily constitute or imply its endorsement, recommendation, or favoring by the United States Government of any agency thereof, or Battelle Memorial Institute. The views and opinions of authors expressed herein do not necessarily state or reflect those of the United States Government or any agency thereof.

\author{
PACIFIC NORTHWEST LABORATORY \\ operated by \\ BATTELLE MEMORIAL INSTITUTE \\ for the \\ UNITED STATES DEPARTMENT OF ENERGY \\ under Contract DE-ACO6-76RLO 1830
}

Printed in the United. States of America

Available to DOE and DOE contractors from the

Office of Scientific and Technical Information, P.O. Box 62, Oak Ridge, TN 37837; prices available from (615) 576-8401. FIS 626-8401.

Available to the public from the National Technical Information Service,

U.S. Department of Commerce, 5285 Port Royal Rd., Springfield, VA 22161

NTIS Price Codes, Microfiche A01

Printed Copy

\begin{tabular}{|c|c|c|c|}
\hline Price Code & Page Range & Price Code & Page Range \\
\hline $\mathrm{A} 02$ & $1-10$ & A15 & $326-350$ \\
\hline $\mathrm{A} 03$ & $1 \mathrm{~T} \cdot 50$ & A16 & $351-375$ \\
\hline $\mathrm{A} 04$ & $51-75$ & A17 & $376-400$ \\
\hline $\mathrm{A} 05$ & $76-100$ & A18 & $401-425$ \\
\hline $\mathrm{A} 06$ & $101-125$ & A19 & $426-450$ \\
\hline A07 & $126-150$ & $\mathrm{~A} 20$ & $451-475$ \\
\hline $\mathrm{A} 08$ & $151-175$ & $\mathrm{~A} 21$ & $476-500$ \\
\hline$A 09$ & $176-200$ & $\mathrm{~A} 22$ & $501-525$ \\
\hline At0 & $201-225$ & A23 & $526-550$ \\
\hline At1 & $226-250$ & A24 & $551-575$ \\
\hline A12 & $251-275$ & A25 & $576-600$ \\
\hline A13 & $276-300$ & A99 & 601-Up \\
\hline A14 & $301-325$ & & \\
\hline
\end{tabular}


PNL -7355

UC -602

INITIAL TESTS ON IN SITU VITRIFICATION USING ELECTRODE FEEDING TECHNIQUES
R. K. Farnsworth
K. H. Oma
C. E. Bigelow

May 1990

Prepared for the U.S. Department of Energy under Contract DE-ACO6-76RLO 1830

Pacific Northwest Laboratory Rich1and, Washington 99352 


\section{SUMMARY}

This report summarizes the results of an engineering-scale in situ vitrification (ISV) test conducted to demonstrate the potential for electrode feeding in soils with a high concentration of metals. The engineering-scale test was part of a Pacific Northwest Laboratory (PNL) program to assist Idaho National Engineering Laboratory (INEL) in conducting treatability studies of the potential for applying ISV to the mixed transuranic waste buried at the INEL subsurface disposal area. The purpose of this test was to evaluate the effectiveness of both gravity fed and operator-controlled electrode feeding in reducing or eliminating many of the potential problems associated with fixedelectrode processing of soils with high concentrations of metal (i.e., electrode shorting, void formation, power 1 imitations). Actual site soils from INEL were mixed with representative concentrations of carbon stee 1 and stainless steel for this engineering-scale test.

The test successfully demonstrated the feasibility and benefits of electrode feeding during ISV processing of INEL soils. The test ran for 34.4 hours, melted to a depth of $89 \mathrm{~cm}$ (35 in.), and produced a $373-\mathrm{kg}$ (822-1b) block of vitrified soil. These data compare favorably with data from the two previous engineering-scale tests on INEL soils, in which fixed electrodes were used. Those tests lasted only 19-20 hours, melted to depths of only 46-51 cm (18-20 in.), and produced vitrified blocks weighing only 142-155 $\mathrm{kg}$ (313-34I lb). In addition, the third test operated much more smoothly than either of the other two tests. The average power input for the electrode feed test was $16 \mathrm{~kW}$, compared to $12.5 \mathrm{~kW}$ and $8.9 \mathrm{~kW}$ for the other engineering-scale tests.

The electrode feed test demonstrated gravity feeding of electrodes following the test startup, until the melt encountered an electrical short. This implies that, for a contaminated soil site where metal pooling is not a consideration, electrode feeding may be possible without the use of a mechanized feed system. The electrode feed test also demonstrated successful recovery 
from a metal short, increased voltage and amperage control between the two electrical phases, reheating of a cooled glass surface, and the elimination of voids in the vitrified melt.

Electrode feeding also eliminates the need for pre-placement of electrodes in contaminated soils before initiating ISV operations. This results in the elimination of costly, hazardous, drilling activities for electrode pre-placement, which creates secondary waste streams and can potentially expose personnel to hazardous or radioactive materials.

Finally, it appears that the use of gravity-fed electrodes can accurately monitor melt depth, provided the electrodes are large enough to withstand corrosion and/or breakage. Accurate depth monitoring was successfully demonstrated during the engineering-scale test for approximately 4 hours following startup. However, in the latter stages of testing, melt depth monitoring appeared to be affected by the electrode corrosion, which eventually caused one of the electrodes to break. At that point, the test was discontinued. While air oxidation was reduced on two of the graphite electrodes that were coated with silicon carbide $(\mathrm{SiC})$, the electrode oxidation just above the melt surface was still significant. In future tests, it is recommended that the oxidation resistance of SiC coatings applied by a painton method should be compared to that of SiC coatings applied by chemical vapor deposition (CVD). Assuming a direct correlation with electrode diameter, typical intermediate-scale operations using $15-\mathrm{cm}$ (6-in.)-diameter uncoated electrodes would be expected to last approximately 100 hours. If all four electrodes were coated with SiC, or the electrodes were continualiy fed downward without being withdrawn for extended periods of time, a significantly longer electrode life would be expected. The use of electrode feeding may also provide a means to recover from electrode failure, by simply reinserting the unbroken portion of the electrode into the vitrified melt. 


\section{CONTENTS}

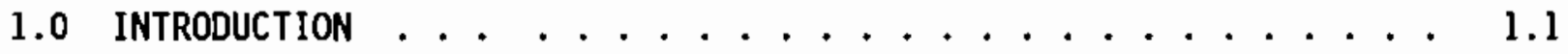

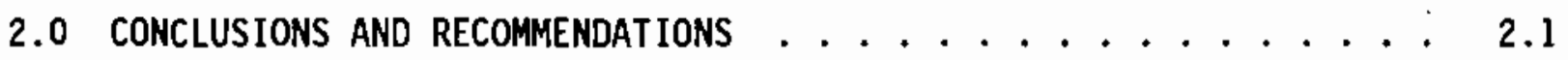

3.0 PROCESS DESCRIPTION AND STATUS OF DEVELOPMENT $\ldots \ldots \ldots . \ldots . . . \ldots$

4.0 TEST DESCRIPTION . . . . . . . . . . . . . . 4.1

4.1 SOIL CHARACTERIZATION ...................... 4.1

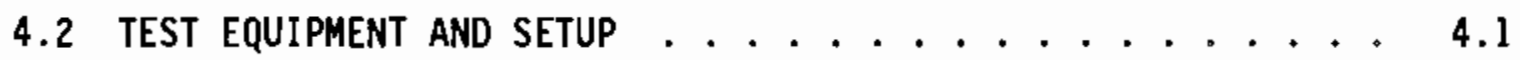

5.0 TESt RESUltS AND PERfORMANCE EVALUATION . . . . . . . . 5.1

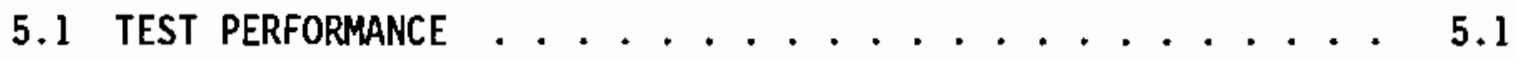

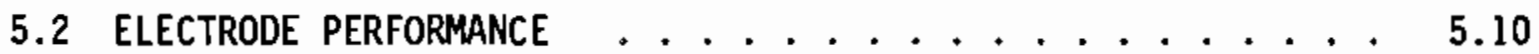

6.0 REFERENCES $\ldots \ldots \ldots \ldots . \ldots \ldots . \ldots . \ldots . \ldots . \ldots$ 


\section{FIGURES}

3.1 The Process of In Situ Vitrification .......... 3.1

4.1 Engineering-Scale Container Used for ISV Processing . . . . . 4.3

4.2 Thermocouple and Soil Configuration for the ES-INEL-3 Test . . 4.4

4.3 Electrode Feed System for the ISV Engineering-Scale Test . . . 4.6

4.4 Electrical Contact Shoes for the ISV Engineering-Scale Electrode Feed System .............. 4.7

5.1 Vitrified Block Resulting from the ES-INEL-3 Test . . . . . . 5.2

5.2 Cross-Section of the ES-INEL-3 Vitrified Block . . . . . . . 5.4

5.3 Electrical Test Data for the ES-INEL-3 Test . . . . . . . . 5.6

5.4 Total Energy Input as a Function of Run Time for the ES-INEL-3 Test . . . . . . . . . . . 5.7

5.5 Melt Depth Versus Proposed Electrode Depths for the ES-INEL-3 Test . . . . . . . . . . . . . . . 5.9

5.6 Reduced Diameter of Uncoated Electrode A-2 vs. Run Time . . . 5.11

5.7 Electrode 0xidation During the Third ISV Engineering-Scale Test ................. 5.12

5.8 Post-Test Observation of Electrode Oxidation on Three of the Four Electrodes .................. 5.13

5.9 Contact Shoe Resistances as a Function of Run Time . . . . . 5.15 


\section{$\underline{\text { TABLES }}$}

3.1 Testing Units for Developing In Situ Vitrification

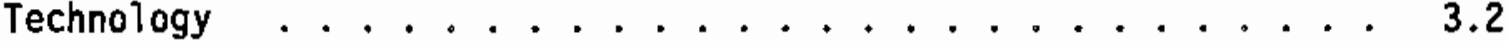

4.1 Results from ICP Sample Analyses of Soil from the ES-INEL-3,

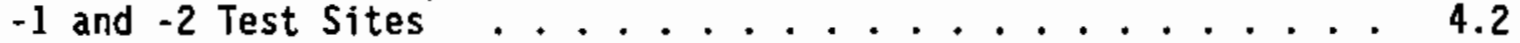

5.1 Comparison of Performance for the Engineering-Scale System $\ldots \quad 5.5$ 
. 


\subsection{INTRODUCTION}

Pacific Northwest Laboratory (PNL) ${ }^{(a)}$ is developing a thermal treatment process that converts contaminated soils into a chemically inert and stable product consisting of glass and crystalline phases. The process, called in situ vitrification (ISV), can be used to treat either radioactive- or hazardous-contaminated soils. The ISV process was initially developed to demonstrate a potential technology for stabilization of soil contaminated with transuranic waste at the Hanford Site in eastern Washington. Tests have shown that many hazardous chemical wastes are also destroyed or immobilized as a result of treatment. The ISV process was originally developed for the U.S. Department of Energy by PNL.

Pacific Northwest Laboratory is assisting the Idaho National Engineering Laboratory (INEL) in conducting treatability studies on the application of ISV to the mixed transuranic (TRU) waste buried at the INEL subsurface disposal area. The ISV process appears to be well suited for remediation of the area, based on preliminary information on the characteristics of waste at the site, depth of the site, and contaminants within the site. However, results from two engineering-scale tests (ES-INEL-1 and ES-INEL-2) performed in FY 1988 (Oma, Reimus and Timmerman 1989) indicated that the ISV technology needs to be modified to improve methods for processing these particular INEL soils, which have a high concentration of metal.

A third engineering-scale test (ES-INEL-3) was conducted in FY 1989 to evaluate the potential for using an electrode feed system (EFS) on INEL soils containing representative concentrations of metal. With electrode feeding, the four electrodes that are used to initiate the ISV process are independently fed to the molten soil as the melt proceeds downward instead of being placed in the soil prior to test startup. The system improves processing control at sites with high concentrations of metal. Upon encountering a full or partial shorting condition, the affected electrodes are simply rajsed and held above the molten metal pool at the bottom of the melt. During this time,

(a) Pacific Northwest Laboratory is operated by Battelle Memorial Institute for the U.S. Department of Energy under Contract DE-AC06-76RLO 1830. 
the melt (and molten metal pool) continues to grow downward. The affected eiectrodes can then be reinserted into the melt to their original depth, and all four electrodes resume electrode feeding operations. Electrode feeding is expected to eliminate many other potential problems that can develop when processing soils containing high concentrations of metals (i.e., power limitations, void formation, electrode preplacement).

Conclusions and recommendations from the engineering-scale electrode feed test (ES-INEL-3) are presented in Section 2 of the report. A description of the ISV process is provided in Section 3 . The setup of the engineering-scale test is described in Section 4, and results from the test are discussed in Section 5 . 


\subsection{CONCLUSIONS AND RECOMMENDATIONS}

The third engineering-scale test of ISV on INEL soils (ES-INEL-3) was completed in April 1989. The test successfully demonstrated the feasibility and benefits of using the electrode feed system during ISV. The conclusions listed below are based on a comparison of the results from this test with those from the previous engineering-scale tests (ES-INEL-1 and ES-INEL-2).

- The vitrified block from ES-INEL-3 weighed $373 \mathrm{~kg}$, compared to blocks weighing $155 \mathrm{~kg}$ and $142 \mathrm{~kg}$ for ES-INEL-1 and -2, respectively. The third test lasted approximately 15 hours longer and produced a higher average power input than either ES-INEL-1 or -2.

- "Gravity feeding" of the electrodes was demonstrated prior to reaching the metal zones, indicating that for a contaminated soil site where metal shorting is not a consideration, electrodes may be self-fed without the assistance of a mechanized feed system.

- Recovery from a metal short was successful when the electrodes were raised above the metal pool that formed at the bottom of the melt zone.

- Voltage and amperage control were greatly enhanced by the ability to independently raise and lower the electrodes. Use of this technique to balance voltage and amperage contributed to a higher average power input than achieved during the ES-INEL-1 and -2 tests.

- The electrode feed system operated extremely well, as evidenced by the ability to rajse and lower the electrodes without breakage at the joints.

- The electrode contact shoes operated as designed. The interface resistance between the shoes and electrodes remained low throughout the test, at an average of 0.22 ohms. At a maximum voltage of $400 \mathrm{~V}$, this results in an average power loss of only $88 \mathrm{~W}$ per contact shoe.

- The 5-cm (2-in.)-diameter graphite electrodes operated for 32 hours before one of the uncoated electrodes oxidized to the point of failure. Assuming a direct correlation with electrode diameter, the 15-cm (6-in.)-diameter, uncoated electrodes typically used during intermediate-scale operations would be expected to last approximately 100 hours. A longer electrode life time would be expected if the electrodes were coated with $\mathrm{SiC}$ or continuously fed to the melt without being withdrawn for extended periods of time.

- The molten glass surface fully subsided without the addition of fluxes. This indicates that raising the electrodes above the molten 
metal pool can result in more uniform heating, thus eliminating or greatly reducing the void spaces that developed during previous tests.

- Although a coating of silicon carbide reduced air oxidation on two of the graphite electrodes, the oxidation just above the melt surface was still significant. The use of coatings or other oxidation prevention methods may be required for large-scale operations.

The following recommendations are made based on the results of this study:

- Plans to use the electrode feed system for the intermediate-scale ISV tests at INEL should proceed. The electrode feed system should alleviate many of the potential problems associated with processing soils that have a high metals concentrations (i.e., electrode shorting, power limitations, void formations, and downward melt growth).

- Further studies of methods to prevent electrode oxidation and corrosion are recommended. These methods include various operational controls and the use of chemical vapor-deposited (CVD) coatings, which are to be tested during the fourth engineering-scale test.

- Future studies on the use of electrode feeding to monitor melt depth are recommended. It may be desirable to find ways to isolate the melt depth measurement from the ISV electrical system, particularly in sites that contain high concentrations of metals. 


\subsection{PROCESS DESCRIPTION AND STATUS OF DEVELOPMENT}

In situ vitrification has been developed as a remedial action process for treating soils contaminated with hazardous chemical wastes or radionuclides. Figure 3.1 illustrates the operation of the ISV process. In the current reference ISV system, a square array of four molybdenum and graphite electrodes is inserted into the ground to the desired treatment depth. Because soil is not electrically conductive when its moisture is driven off, a conductive mixture of flaked graphite and glass frit is placed among the electrodes to act as a starter path. An electrical potential is applied to the electrodes to establish an electrical current in the starter path. The resultant power heats the starter path and surrounding soil to $1600^{\circ} \mathrm{C}$ to $2000^{\circ} \mathrm{C}$, well above the initial soil melting temperatures of $1100^{\circ} \mathrm{C}$ to $1450^{\circ} \mathrm{C}$. The graphite starter path is eventually consumed by oxidation and the current is transferred to the molten soil, which is processed at temperatures between $1450^{\circ} \mathrm{C}$ and $2000^{\circ} \mathrm{C}$. As the molten or vitrified zone grows, it incorporates radionuclides and nonvolatile hazardous elements, such as heavy metals, while destroying organic components by pyrolysis. The pyrolyzed byproducts migrate to the surface of the vitrified zone, where they combust in the presence of oxygen. A hood placed over the area being vitrified directs the gaseous effluents to an off-gas treatment system.

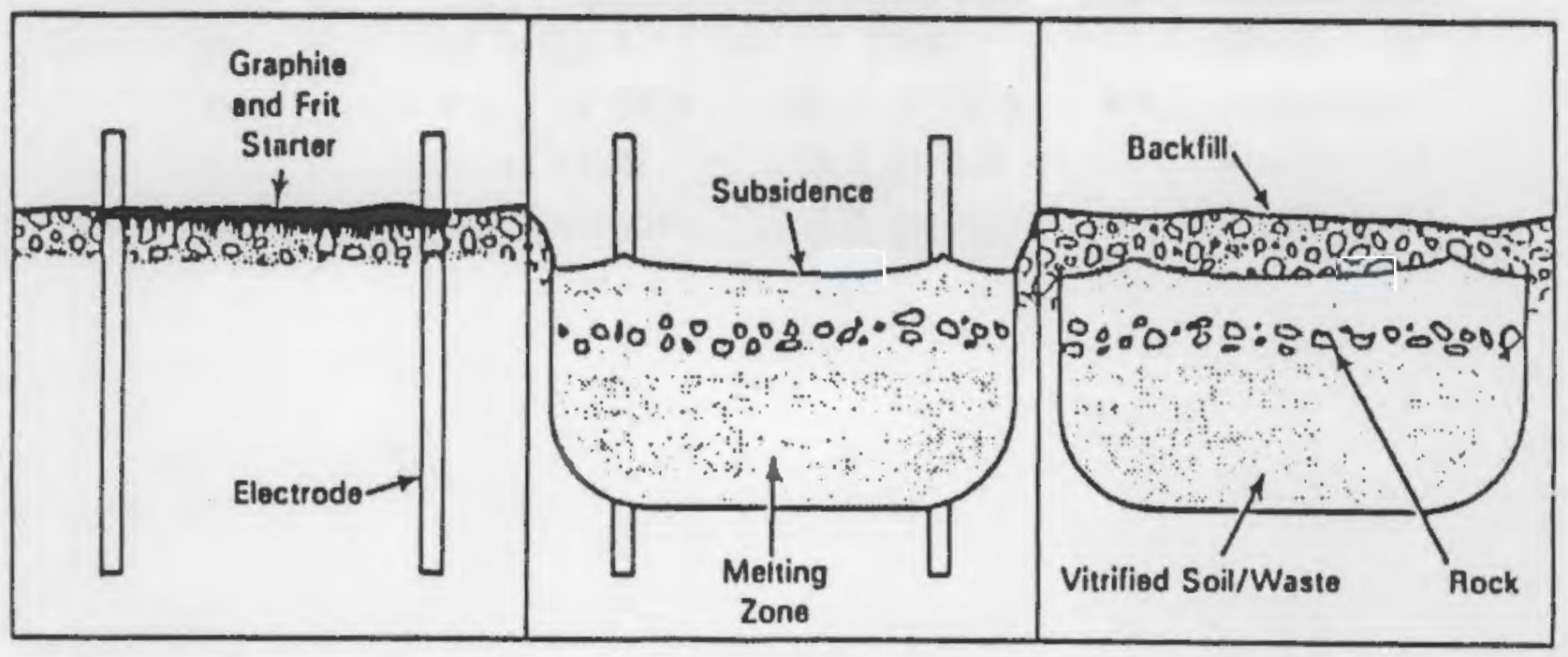

FIGURE 3.1. The Process of In Situ Vitrification 
Since PNL began developing the ISV technology, numerous experimental tests under a variety of conditions have been conducted (Buelt et al. 1987; Timmerman and Oma 1984; Timmerman et a1. 1983; Buelt and Carter 1986; Carter, Bates and Maupin 1987). Table 3.1 lists the different scales of testing units that PNL used in developing ISV technology. The successful results of 74 bench-, engineering-, pilot-, and large-scale tests have proven the feasibility of the process. Also, economic studies have indicated that tremendous economies of scale are attainable with the ISV process (Oma et a1. 1983).

Recent ISV tests with INEL soils have focused on soils containing a large concentration of meta7. Because of the potential for unrecoverable shorting conditions, a new electrode feeding technique has been designed. With electrode feeding, the electrodes are continually inserted into the melt as the melt grows downward. The new technique would allow for recovery from a metal short, by simply raising the moving electrodes above the molten metal pool, until the Joule heating condition is reestablished. This third test of INEL soils is the first test to demonstrate the new electrode feeding technique.

TABLE 3.1. Testing Units for Developing In Situ Vitrification Technology

\begin{tabular}{|c|c|c|c|}
\hline Equipment Size & $\begin{array}{c}\text { Electrode } \\
\text { Separation, } m\end{array}$ & $\begin{array}{l}\text { Block } \\
\text { Size }\end{array}$ & $\begin{array}{l}\text { Tests Completed } \\
\text { As of } 1 / 26 / 90\end{array}$ \\
\hline Bench-Scale & 0.11 & 1 to $10 \mathrm{~kg}$ & 19 \\
\hline Engineering-Scale & 0.23 to 0.36 & 0.05 to $1.0 \mathrm{t}$ & 33 \\
\hline Pilot-Scale & 0.9 to 1.5 & $10 \mathrm{t}_{0} 50 \mathrm{t}$ & 17 \\
\hline Large-Scale & 3.5 to 5.5 & 400 to $800 \mathrm{t}$ & 5 \\
\hline
\end{tabular}




\subsection{TEST DESCRIPTION}

The primary objective of the ES-INEL-3 test was to determine the effectiveness of the electrode feed system in treating soils containing representative amounts of metals and combustibles. A second objective was to determine if electrode feeding eliminates many of the problems associated with soils containing high concentrations of metals (e.g., electrode shorting, void formation, power limitations, etc.). The test was performed using the engineering-scale ISV test equipment and off-gas system.

\subsection{SOIL CHARACTERIZATION}

Prior to setting up the engineering-scale test, samples of the test soil were characterized using inductively coupled plasma (ICP) analysis to determine if the test soil was representative of the soils used during the first two engineering-scale tests. Table 4.1 compares the cation oxide data for soil samples taken from each test site. The soil from the ES-INEL-3 test site is similar to that at the ES-INEL-1 and -2 test sites, so the results from the third test can be compared with results from the first two tests to better evaluate electrode feeding performance on INEL soils. In addition, the ICP analyses confirm that an acceptable ratio of glass-forming constituents exists to make an acceptable glass product, even if the melting temperature of INEL soils is relatively high. The properties of INEL soils are discussed in a previously published report [Oma, Reimus and Timmerman (1989)].

\subsection{TEST EQUIPMENT AND SETUP}

The test was performed in the ISV engineering-scale processing container (Figure 4.1). The container measures $1.8 \mathrm{~m}(6 \mathrm{ft})$ in diameter by $2.4 \mathrm{~m}(8 \mathrm{ft}$ ) tall and is maintained at a slight negative pressure, with back-pressure HEPAfiltered relief on its lid to prevent particulate releases during testing. off-gases generated during ISV processing are swept out of the processing container by an off-gas system. The test was operated at an off-gas flow of $6001 \mathrm{pm}(21 \mathrm{scfm})$. 

TABLE 4.1. Results from ICP Sample Analyses of Soil from the
ES-INEL-3, -1 and -2 Test Sites

\begin{tabular}{|c|c|c|}
\hline Oxide & $\begin{array}{l}\text { ES-INEL-3: Soil } \\
\text { Composition, wt\% }\end{array}$ & $\begin{array}{l}\text { ES-INEL-1 \& -2: }\{00 j \\
\text { Composition, wt\%(a) }\end{array}$ \\
\hline $\mathrm{SiO}_{2}$ & 68.15 & 62.60 \\
\hline $\mathrm{Al}_{2} \mathrm{O}_{3}$ & 12.75 & 11.85 \\
\hline $\mathrm{Fe}_{2} \mathrm{O}_{3}$ & 4.15 & 4.25 \\
\hline $\mathrm{CaO}$ & 3.66 & 3.68 \\
\hline $\mathrm{K}_{2} \mathrm{O}$ & 2.95 & 2.99 \\
\hline $\mathrm{MgO}$ & 1.72 & 1.72 \\
\hline $\mathrm{Na}_{2} \mathrm{O}$ & 1.56 & 1.37 \\
\hline $\mathrm{TiO}_{2}$ & 0.68 & 0.68 \\
\hline $\mathrm{MnO}_{2}$ & 0.12 & 0.10 \\
\hline $\mathrm{BaO}$ & 0.09 & 0.09 \\
\hline $\mathrm{ZrO}_{2}$ & 0.07 & 0.05 \\
\hline $\mathrm{B}_{2} \mathrm{O}_{3}$ & $<0.05$ & 0.05 \\
\hline Sro & 0.03 & 0.02 \\
\hline $\mathrm{V}_{2} \mathrm{O}_{3}$ & 0.02 & $<0.01$ \\
\hline $\mathrm{NiO}$ & $<0.02$ & 0.04 \\
\hline $\mathrm{Cr}_{2} \mathrm{O}_{3}$ & $\leq 0.02$ & $\underline{0.02}$ \\
\hline Total Oxide & $95.9 \%$ & $89.5 \%$ \\
\hline Moisture & $6.9 \%$ & $7.5 \%$ \\
\hline
\end{tabular}

(a) Soil compositions averaged from two analyses of soil samples.

(b) Data taken from Oma, Reimus and Timmerman (1989).

Figure 4.2 shows the soil and thermocouple configuration that was used for this engineering-scale test. Three $20-\mathrm{cm}$ (8-in.)-thick layers of INEL soil were placed in the container, with each layer containing uniform concentrations of carbon steel and stainless steel in a 50:50 mixture. The first soil layer was buried 30 to $51 \mathrm{~cm}$ (12 to 20 in.) below grade and contained a metal concentration of $5.8 \mathrm{wt} \%$. The second layer was buried 51 to $71 \mathrm{~cm}$ (20 to 28 in.) below grade and contained 11.6 wt\% metal. Finally, the third 


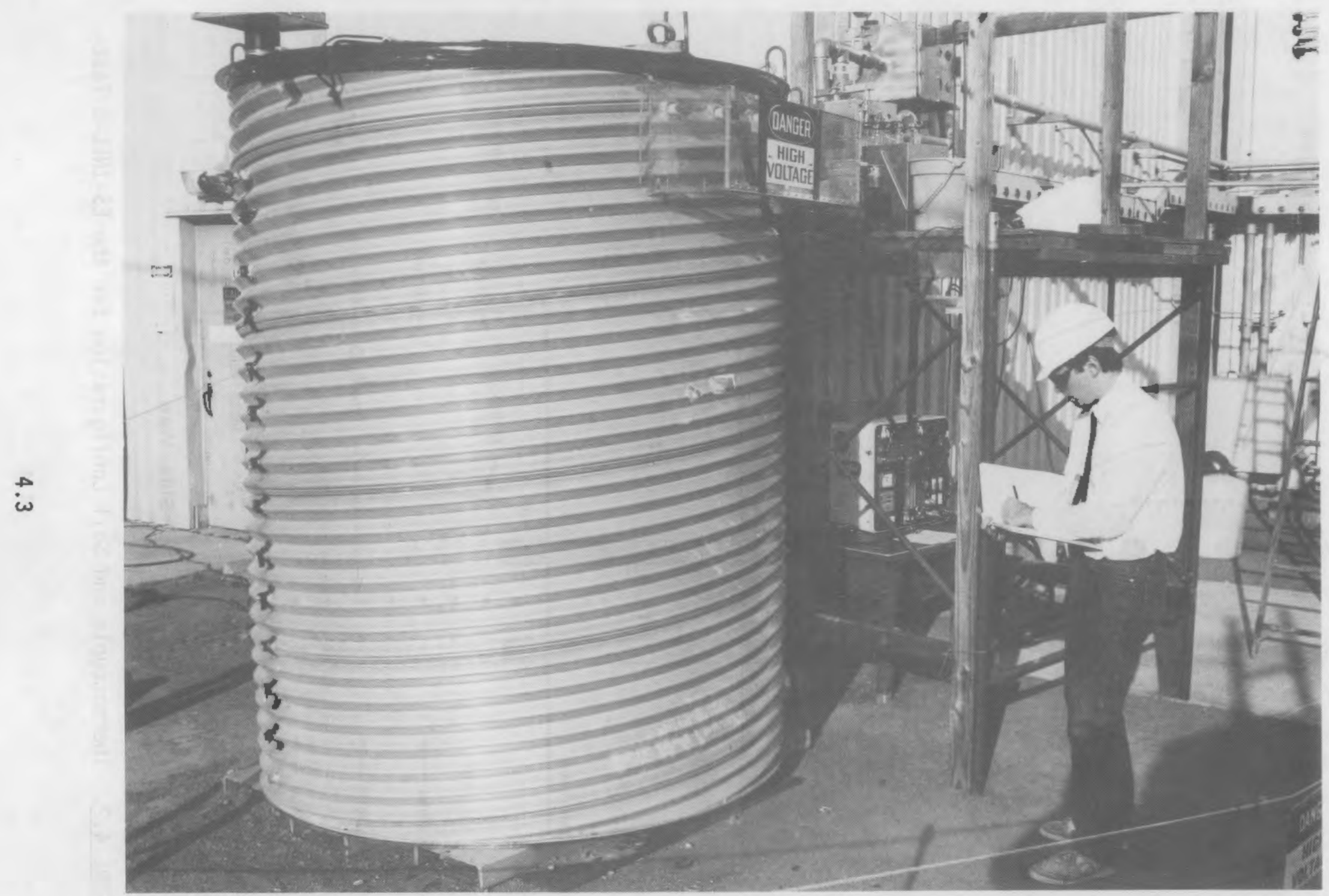

FIGURE 4.1. Engineering-Scale Container Used for ISV Processing 

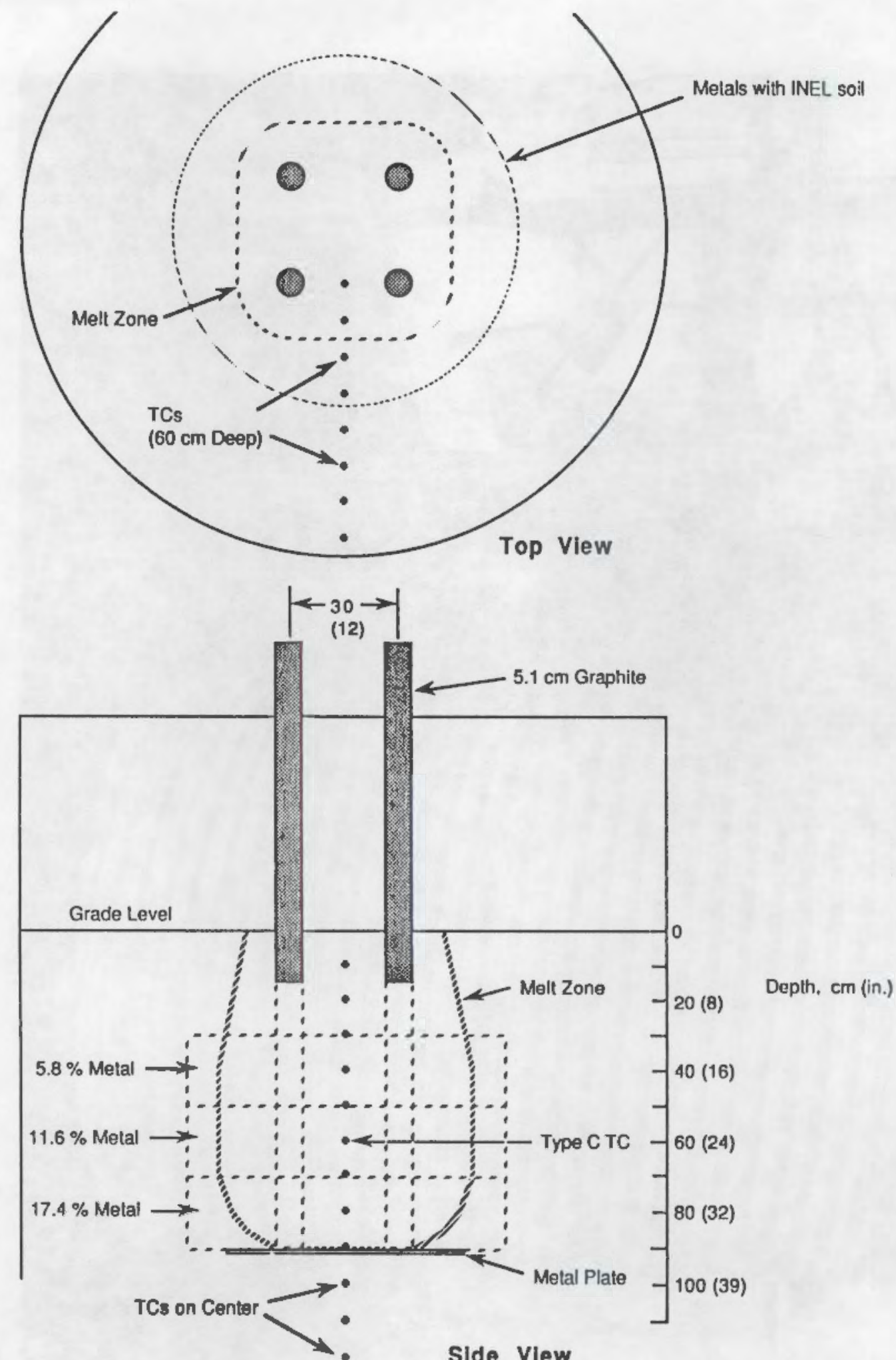

Side View

FIGURE 4.2. Thermocouple and Soil Configuration for the ES-INEL-3 Test 
layer was buried 71 to $91 \mathrm{~cm}$ ( 28 to $36 \mathrm{in.}$ ) below grade and contained 17.4 wt\% metal. The amount of metal present in each of the three soil layers was equivalent to $50 \%, 100 \%$, and $150 \%$, respectively, of the maximum metal concentration expected in the INEL subsurface disposal area. The three soil layers were covered by $30 \mathrm{~cm}$ (12 in.) of INEL cover soil.

In addition, a $63.5-\mathrm{cm}(25-\mathrm{in}$.$) -square piece of 0.48-\mathrm{cm}(3 / 16-\mathrm{in.})$ stainless steel plate was $\mathrm{placed} 91 \mathrm{~cm}$ ( $36 \mathrm{in.}$ ) below grade to evaluate the effect of a full shorting potential on electrode feeding performance. However, the test was terminated by a failed electrode before the vitrification zone reached the stainless steel plate.

The electrode feed system (Figure 4.3) was used to feed four graphite electrodes into the melt. The system consists of a stationary guide ring at the top of the assembly, a movable gripper/guide ring for operator-controlled electrode feeding, and a bottom guide ring with two electrical contact shoes for each electrode. The electrical contact shoes (Figure 4.4) grip each electrode in a manner that permits continuous feeding of the electrode while maintaining full power. The system was operated using both gravity feeding and operator-controlled feeding of the electrodes. For operator-controlled feeding, the air-operated drive motor and gripper are used to control the upward and downward movement of each electrode. The capability for operatorcontrolled feeding is necessary during ISV melts in which a full or partial shorting potential exists because of the high concentrations of metals in the melt. Air regulators on the supply lines to the air motor and gripper permit a wide range of operating speeds and gripping forces.

Each electrode was $5.1 \mathrm{~cm}$ (2.0 in.) in diameter and consisted of four 56 to 61-cm (22- to 24-in.)-long graphite sections joined by male/female connections, for a total length of 234 to $236 \mathrm{~cm}$ (92 to $93 \mathrm{in.}$ ). The electrodes were initially inserted into the INEL cover soil to $15 \mathrm{~cm}$ ( 6 in.) below grade, and were spaced in a $30.5 \mathrm{~cm} \times 30.5 \mathrm{~cm}$ (12 in. $\times 12$ in.) square array (see Figure 4.2). Two of the electrodes were coated with Zyp Type SC, a silicon carbide-coating; the other two electrodes were left uncoated. After 


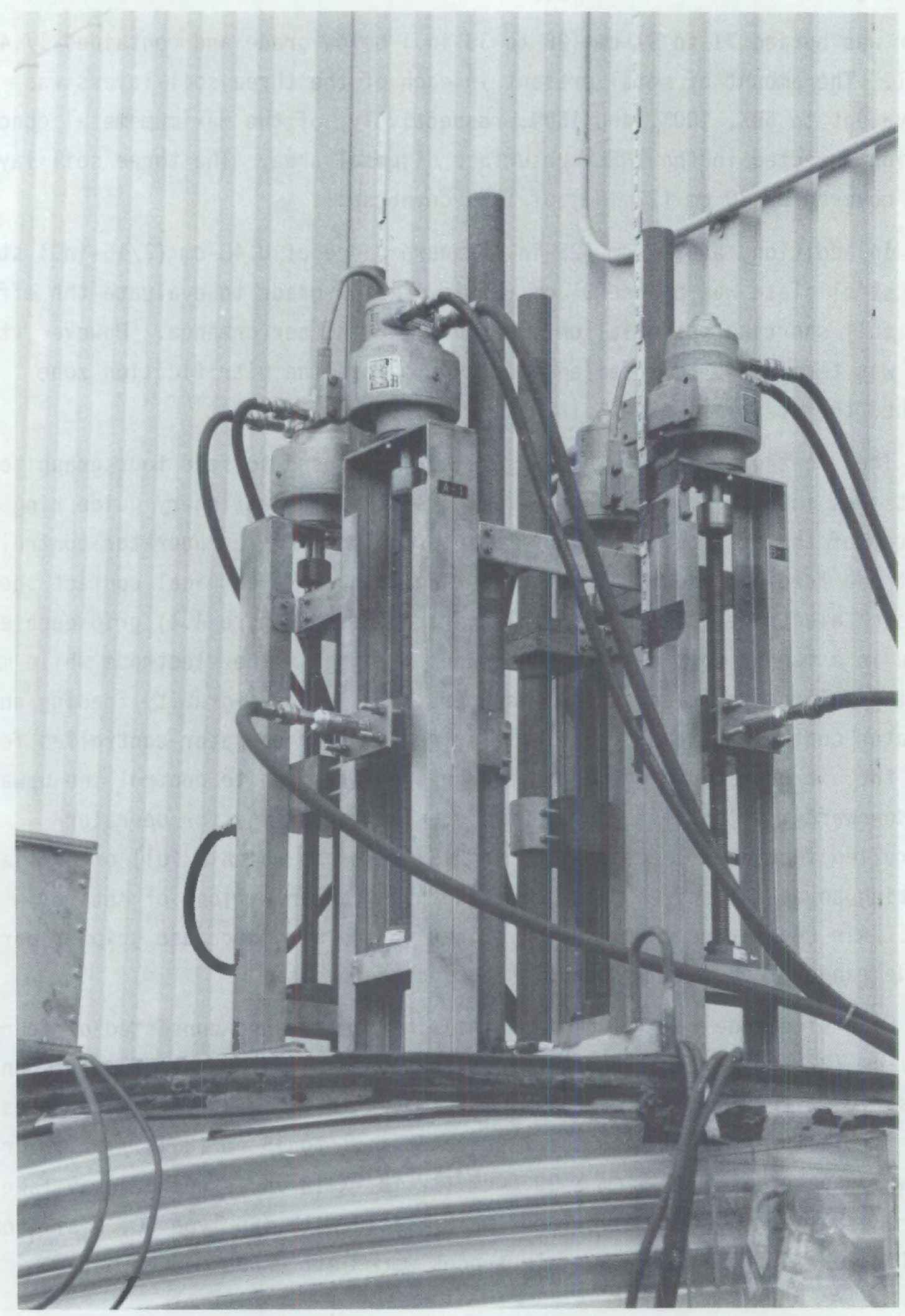

FIGURE 4.3. Electrode Feed System for the ISV Engineering-Scale Test 


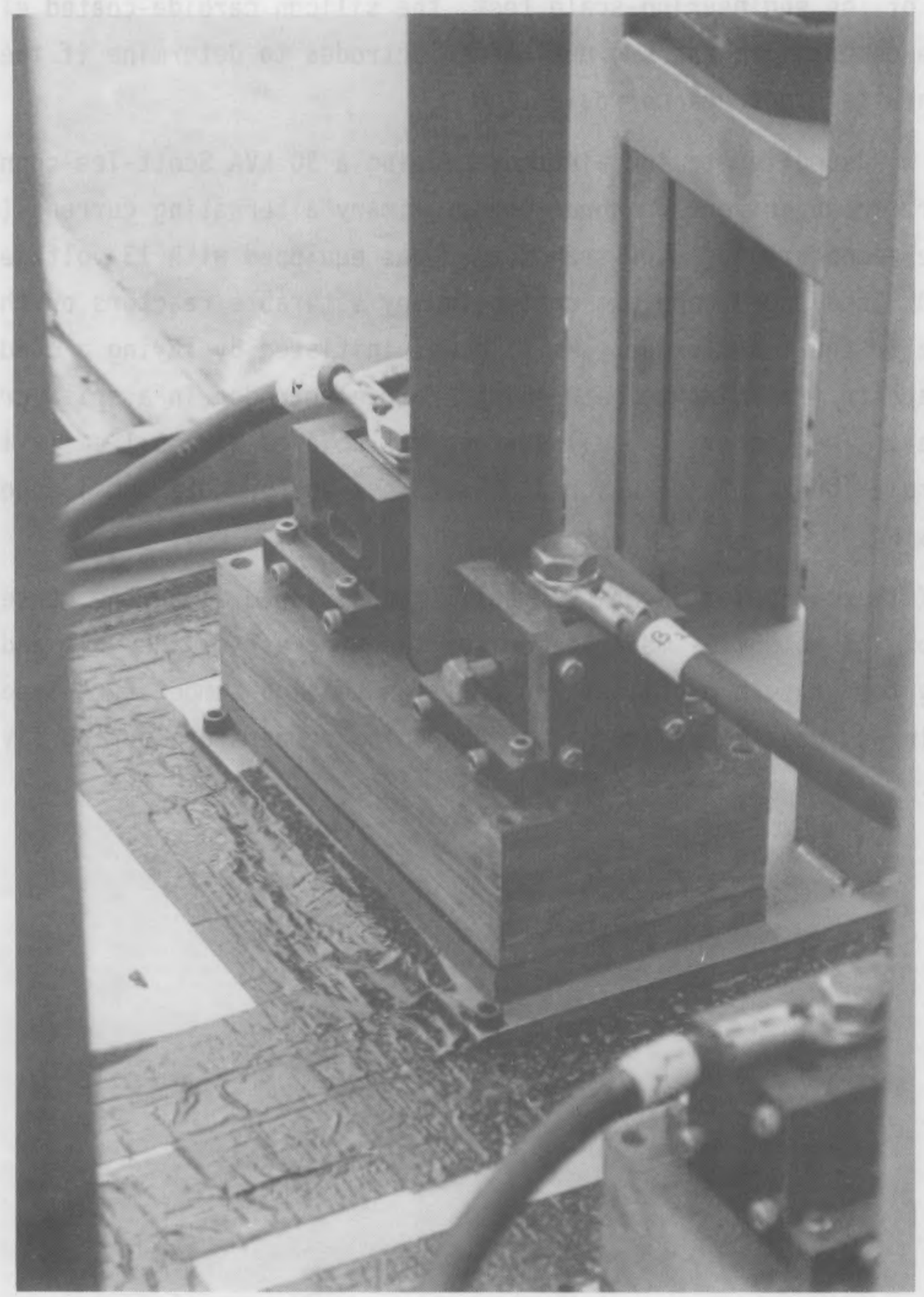

FIGURE 4.4. Electrical Contact Shoes for the ISV Engineering-Scale Electrode Feed System 
completion of the engineering-scale test, the silicon carbide-coated electrodes were compared to the two uncoated electrodes to determine if the coating inhibits electrode corrosion.

Power was supplied to the electrodes using a 30 kVA Scott-Tee-connected transformer, which converts a three-phase primary alternating current (AC) to a two-phase secondary AC. The transformer was equipped with 13 voltage taps between $400 \mathrm{~V}$ and $100 \mathrm{~V}$, and was controlled by saturable reactors on the secondary side of the transformer. Melting was initiated by laying a conductive path of graphite/frit mixture between the four electrodes in a criss-crossed, square array. The top of the soil surface was covered with $5.1 \mathrm{~cm}(2 \mathrm{in.})$ of blanket insulation to minimize surface heat loss and promote subsidence during ISV processing.

Type $\mathrm{K}$ thermocouples were incrementally positioned along the centerline and sides of the potential melt to monitor the progress of the melt and surrounding temperature profiles. In addition, a high-temperature Type $C$ thermocouple was used to determine the operating temperature during ISV processing. 


\subsection{TEST RESULTS AND PERFORMANCE EVALUATION}

The ES-INEL-3 test was performed on April 24, 25, and 26, 1989. The ISV process produced a $373 \mathrm{~kg}(822 \mathrm{lb})$ glass block over 34.4 hours, and the feasibility and benefits of electrode feeding during ISV were successfully demonstrated. The following sections describe the test results based on ISV process performance and graphite electrode performance.

\subsection{TEST PERFORMANCE}

The ES-INEL-3 test achieved a melt depth of $0.89 \mathrm{~m}$ (35 in.) before it was discontinued 34.4 hours after the test began. Testing was discontinued when one of the two A-phase electrodes oxidized to the point of failure, and efforts to reinsert the electrode into the melt proved unsuccessful. Nevertheless, the process effectively vitrified through three soil layers with localized metal contents of $5.8 \mathrm{wt} \%, 11.6 \mathrm{wt} \%$, and $17.4 \mathrm{wt} \%$, respectively (see Section 4.2). The power system performed well during ISV processing, without being hampered by the partial or full shorting conditions that were observed during the previous engineering-scale tests in which the fixed electrode design was used (Oma, Reimus and Timmerman 1989). Furthermore, the use of electrode feeding in this test did not require any special efforts to eliminate the shorting potentials that may have prevented ISV processing with the fixed electrode design.

Figure 5.1 is a photograph of the vitrified block. The block was $0.89 \mathrm{~m}$ (35 in.) tall, with a maximum diameter of $0.77 \mathrm{~m}$ (30 in.) at $53 \mathrm{~cm}$ (21 in.) below the top of the block. The surface of the vitrified block appeared to be fully subsided at $51 \mathrm{~cm}$ (20 in.) below grade [a partial bridge was observed $20 \mathrm{~cm}$ ( 8 in.) below grade]. This characteristic is in contrast with blocks produced during previous engineering-scale tests in which fixed electrodes were used, and that showed only slight subsidence. Electrode feeding provides a more balanced power distribution that allows the molten glass surface to remain soft enough to continually subside as the melt proceeds downward. 


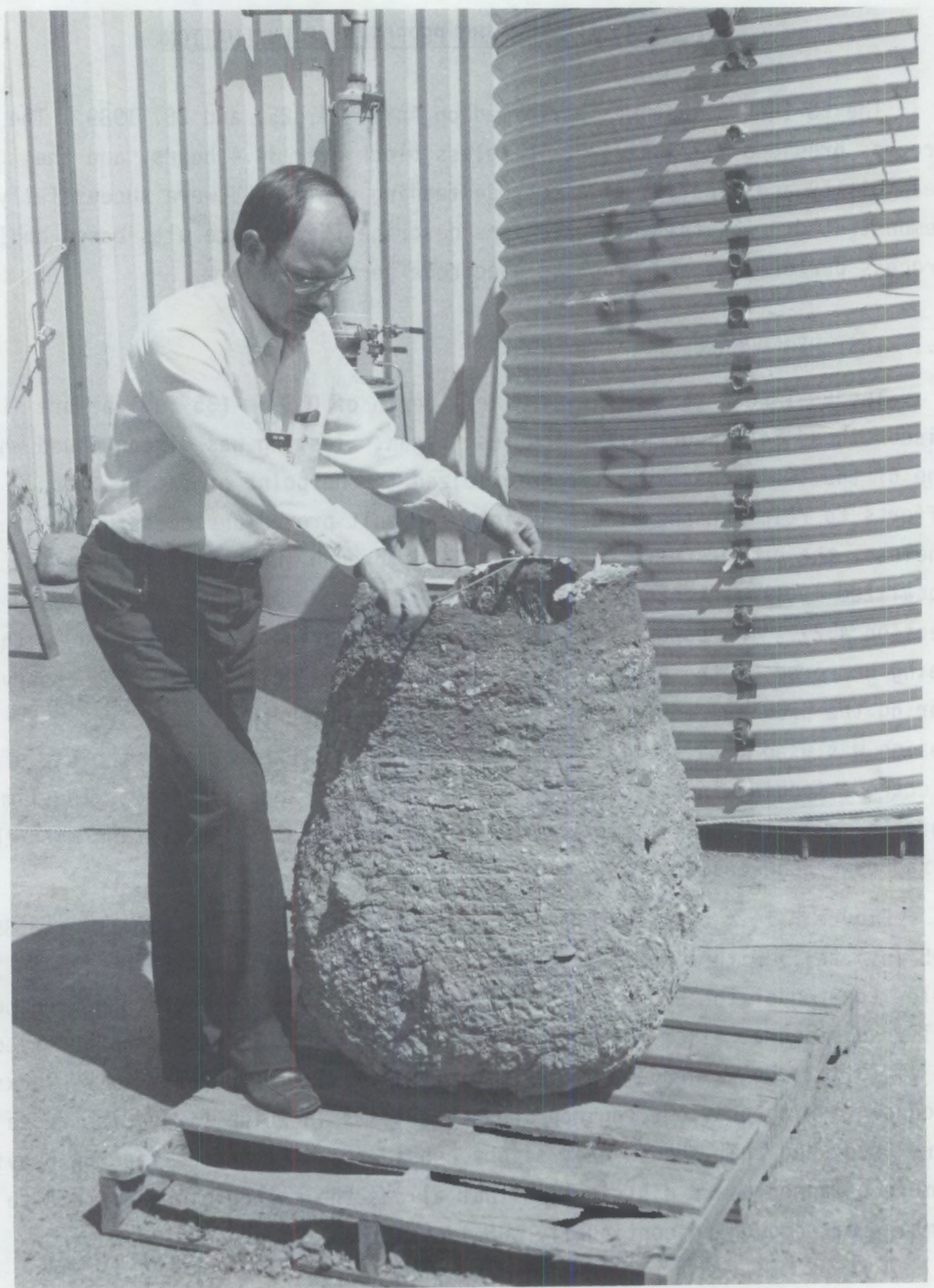

FIGURE 5.1. Vitrified Block Resulting from the ES-INEL-3 Test 
Figure 5.2 shows a cross-section of the vitrified block. As shown in the photograph, the block contained a relatively small volume of void space located just beneath the subsided glass surface. Previous engineering-scale tests of INEL soil resulted in significant void volumes within each vitrified block (Oma, Reimus, and Timmerman 1989). The reduction in void space within the ES-INEL-3 test block is primarily due to the more balanced power distribution that results from electrode feeding.

Performance data for the test are listed in Table 5.1. Included in this table are performance data for the first two engineering-scale tests performed in FY 1988 (Oma, Reimus and Timmerman 1989). A mass balance of the metal retained in the soil showed that the total metals concentration in the vitrified block was 12.4 wt\%. This compares to metal contents of $12.5 \mathrm{wt} \%$ and $15.9 \mathrm{wt} \%$, respectively, for the blocks produced in the ES-INEL-1 and -2 tests. Because of the similarity in metals content, any differences between the third test and the first two tests can be attributed primarily to the use of electrode feeding.

The vitrified block produced during the ES-INEL-3 test was $150 \% 1$ arger than the two vitrified blocks from the ES-INEL-1 and ES-INEL-2 tests, in which a fixed electrode design was used. In addition, the third test showed a significantly greater run time, melt depth, melt width, and total energy input than either of the first two tests. These differences are primarily due to the use of electrode feeding during the ES-INEL-3 test, which allowed the test to continue for a longer period of time than the ES-INEL-1 or -2 tests, without encountering any disabling electrical shorts. In addition, the use of electrical feeding resulted in a more balanced electrical system that increased the average power level to the ES-INEL-3 test.

Figure 5.3 illustrates the electrical data for the ES-INEL-3 test. In contrast to the first two tests, the measured test voltages and amperages (and resultant resistances) were relatively balanced between electrical phases, implying that system voltage and amperage control is greatly enhanced by the ability to independently raise and lower electrodes. Over 550 kWh was provided to the melt during the $\mathbf{3 4 . 4}$ hours of ISV processing, for an average power input of $16.0 \mathrm{~kW}$. This average was significantly greater than the 


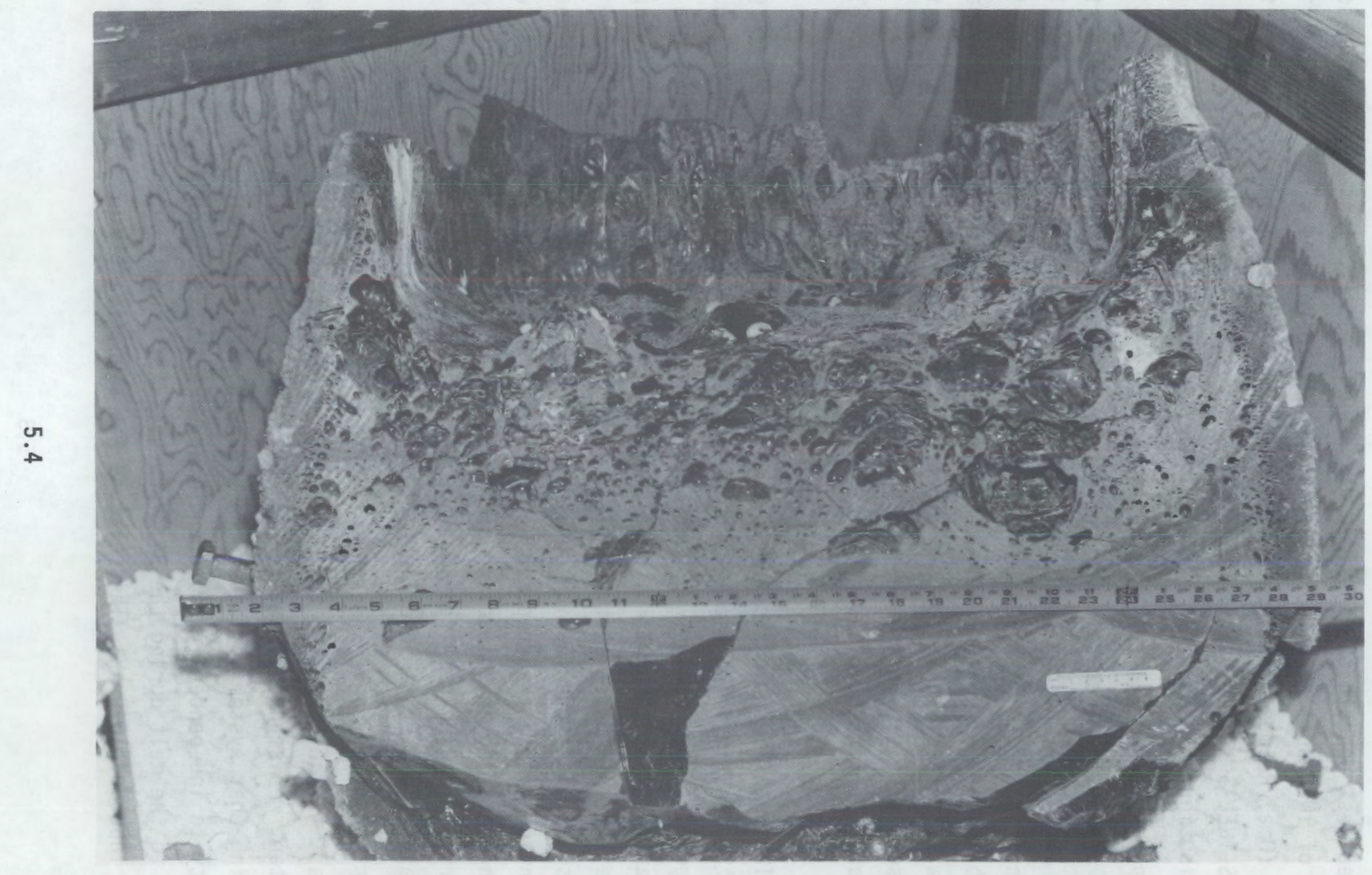

FIGURE 5.2. Cross-Section of the ES-INEL-3 Vitrified Block 
IABLE 5.1. Comparison of Performance for the Engineering-Scale System

\begin{tabular}{|c|c|c|c|}
\hline Parameter & $\begin{array}{c}\text { ES-INEL-3 } \\
\text { (Electrode } \\
\text { Feeding) } \\
\end{array}$ & $\begin{array}{l}\text { ES-INEL-1 (a) } \\
\text { (Fixed } \\
\text { Electrodes) } \\
\end{array}$ & $\begin{array}{l}\text { ES-INEL-2(a) } \\
\text { (Fixed } \\
\text { Electrodes) }\end{array}$ \\
\hline Total run time & $34.4 \mathrm{hr}$ & $18.9 \mathrm{hr}$ & $19.9 \mathrm{hr}$ \\
\hline Vitrified glass wt & $373.0 \mathrm{~kg}$ & $154.0 \mathrm{~kg}$ & $142.0 \mathrm{~kg}$ \\
\hline Soil vitrified (estimate) & $418.0 \mathrm{~kg}$ & $187.0 \mathrm{~kg}$ & $172.0 \mathrm{~kg}$ \\
\hline Melt depth & $\begin{array}{c}0.89 \mathrm{~m} \\
(35.0 \text { in. })\end{array}$ & $\begin{array}{c}0.69 \mathrm{~m} \\
(27.0 \text { in. })\end{array}$ & $\begin{array}{c}0.66 \mathrm{~m} \\
(26.0 \mathrm{in.})\end{array}$ \\
\hline Melt width & $\begin{array}{c}0.77 \mathrm{~m} \\
(30.0 \text { in. })\end{array}$ & $\begin{array}{c}0.51 \mathrm{~m} \\
(20.0 \mathrm{in.})\end{array}$ & $\begin{array}{c}0.46 \mathrm{~m} \\
(18.0 \text { in. })\end{array}$ \\
\hline Average power & $16.0 \mathrm{~kW}$ & $12.5 \mathrm{~kW}$ & $8.9 \mathrm{~kW}$ \\
\hline Total energy & $550.0 \mathrm{kWh}$ & $202.0 \mathrm{kWh}$ & $171.0 \mathrm{kWh}$ \\
\hline Energy-to-mass ratio & $1.3 \mathrm{kWh} / \mathrm{kg}$ & $1.3 \mathrm{kWh} / \mathrm{kg}$ & $1.2 \mathrm{kWh} / \mathrm{kg}$ \\
\hline Metals content & $12.4 w t \%$ & $12.5 w t \%$ & $15.9 w t \%$ \\
\hline
\end{tabular}

(a) Oma, Reimus and Timmerman (1989).

average power inputs for the ES-INEL-1 and -2 tests $(12.5$ and $8.9 \mathrm{~kW}$, respectively). The increased power input for the third test is primarily due to the capability of the electrode feed system to avoid the electrical shorting conditions that lower the average power input. However, the balanced voltages and amperages between the A- and B-phases also contributed to the higher average power input.

The energy-to-mass ratio of the resultant vitrified block was $1.3 \mathrm{kWh} / \mathrm{kg}$ of soil--slightly higher than typical ISV melt ratios of 0.8 to $1.1 \mathrm{kWh} / \mathrm{kg}$. However, similar energy-to-mass ratios were observed from the other two INEL engineering-scale tests. The increased energy-to-mass ratios may be due to the relatively higher melting temperature of INEL soil, or the large concentration of metal in the INEL soil.

After initiating the test, 6 to 7 hours were required to burn the graphite frit startup path and initiate melting. The lengthy startup time was due to an excessively large graphite path and a significant amount of moisture in 

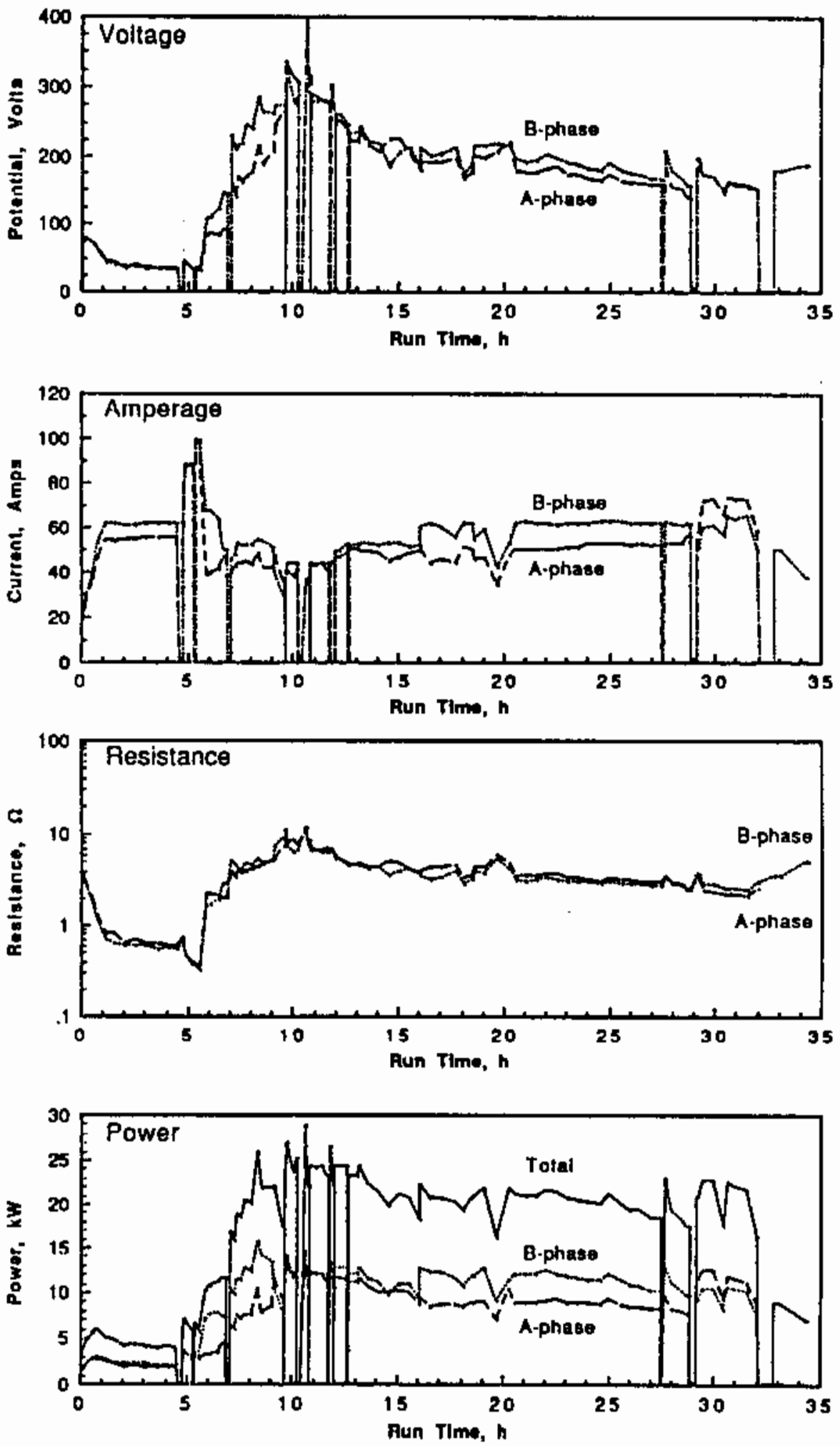

FIGURE 5.3. Electrical Test Data for the ES-INEL-3 Test 
the INEL soil (the test was set up during a rain storm). However, after melting was initiated, the test proceeded smoothly. Figure 5.4 illustrates the amount of energy input to the melt as a function of run time. After the first 7 hours of startup, the rate of energy input remained relatively constant through the next 25 hours of testing. This rate decreased only during the last 2.4 hours of testing, after one of the electrodes failed.

During the 25 hours following startup, the average power level was $20.0 \mathrm{~kW}$. With the electrode cross-sectional area at $929 \mathrm{~cm}^{2}\left(144 \mathrm{in}^{2}\right)$, the power density for this test was $215 \mathrm{~kW} / \mathrm{m}^{2} \cdot\left(20.0 \mathrm{~kW} / \mathrm{ft}^{2}\right)$. This is slightly less than the $286 \mathrm{~kW} / \mathrm{m}^{2}\left(26.6 \mathrm{~kW} / \mathrm{ft}^{2}\right)$ power density of the large-scale ISV system. Despite the lower power density, the use of electrode feeding kept the vitrified surface molten enough to keep the electrodes moving freely.

Both gravity and operator-controlled feeding of the electrodes were successfully demonstrated during this engineering-scale test. Gravity feeding was used for the first 4 to 5 hours after the melt had grown to a depth sufficient to free the electrodes (9.6 to 10.3 hours following test startup). During gravity feeding, the electrodes were allowed to independently sink into the vitrified melt as the melt proceeded downward. At 14.4 hours following test startup, an electrical shorting condition was encountered in both the $A$

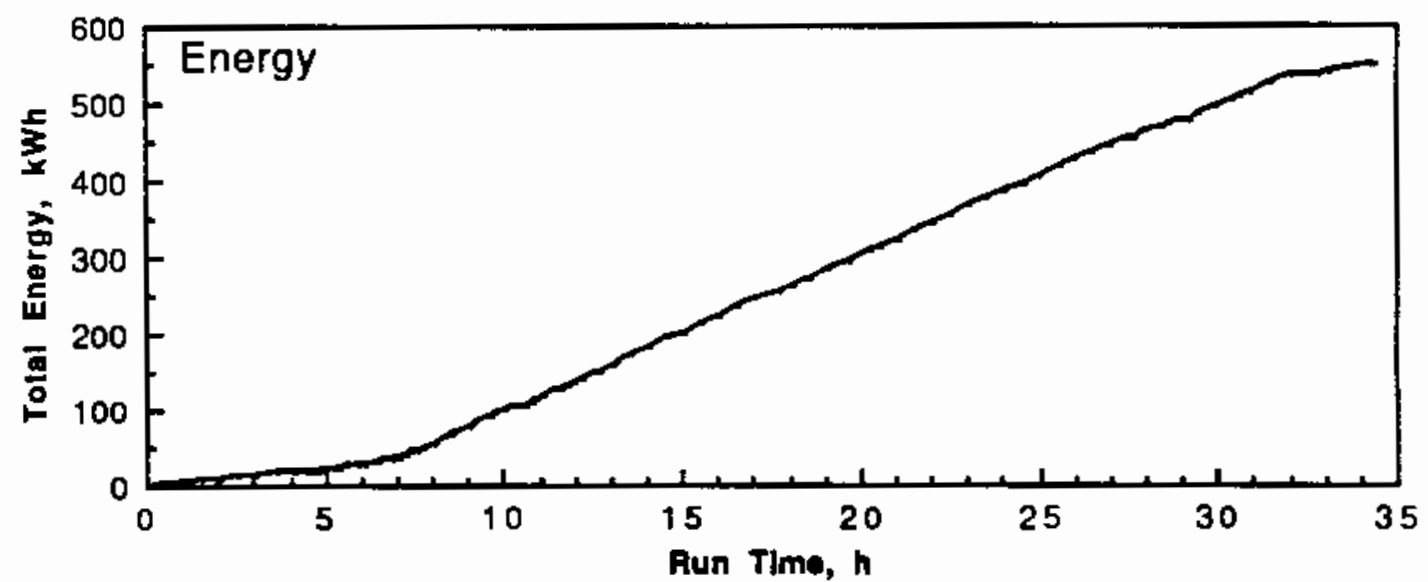

FIGURE 5.4. Total Energy Input as a Function of Run Time for the ES-INEL-3 Test 
and $B$ phases. This implies that electrode feeding without a mechanized feed system may be possible for contaminated soil sites where metal pooling is not a consideration.

Upon encountering the electrical short, the system was switched to operator-controlled electrode feeding. The shorting condition was then eliminated by simply raising the electrodes approximately $5 \mathrm{~cm}(2 \mathrm{in.})$ above the metal pool that was forming at the bottom of the melt zone. Raising the electrodes above the pool balanced the electrical system and effectively demonstrated the ability of the electrode feed system to successfully recover from a metal short.

The electrodes were raised again 18.6 hours after test startup to permit reheating of the cooling glass surface, which was starting to bind the two coated electrodes. The electrodes were held at the 46-cm (18-in.) depth for 2 hours until the glass surface was soft enough to continue electrode feeding. This effectively demonstrated the ability of the electrode feed system to successfully reheat a cooled glass surface.

During testing, the electrode depth was determined based on the height of each electrode above the melt surface. The electrode depths were then plotted against the projected depth of the vitrified melt, based on thermocouple data, to determine if melt depth could be monitored by electrode feeding. The plot of melt depth and electrode depth is shown in Figure 5.5. The graphite electrodes were effectively used to monitor melt depth during gravity feeding until the short required that the electrodes be raised. The electrodes were then effectively held for a total of 6 hours (over two different periods) before resuming downward feeding.

Upon resuming downward electrode feeding, it appeared that the electrode depths eventually surpassed the vitrified melt depth. This may be due to general inaccuracies in the centerline thermocouple position at greater depths. However, it also may be due to the significant amount of corrosion that accumulated on each of the electrodes as they were held at the same level for 6 hours (see Section 5.2). The effect of electrode corrosion on the measurement of melt depth with electrode feeding is currently only speculative. 


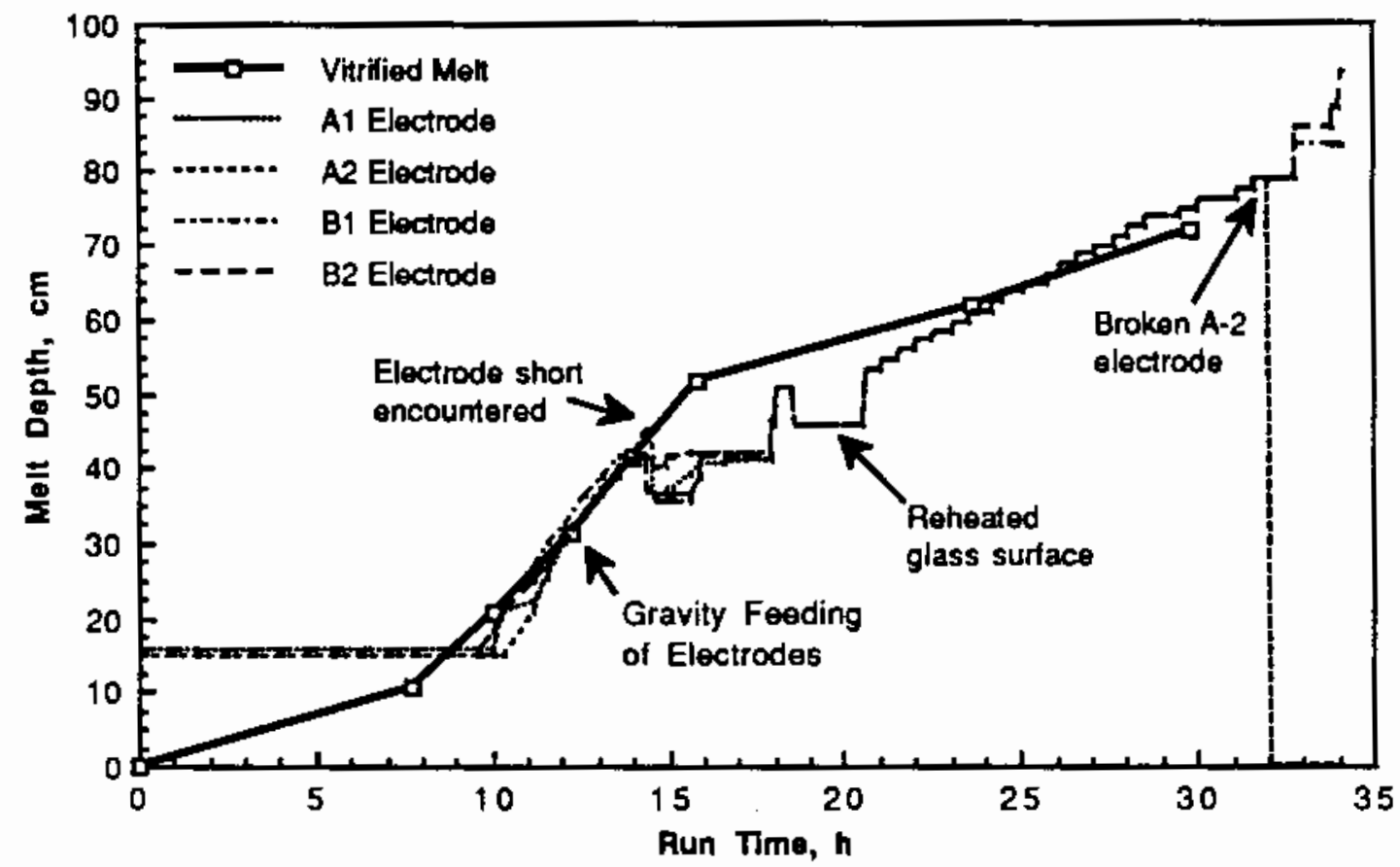

EIGURE 5.5. Melt Depth Versus Proposed Electrode Depths for the ES-INEL-3 Test (based on thermocouple data)

The results imply that melt depth could be continuously monitored by gravity feeding of electrodes on contaminated sites where metal pooling is not a consideration. This assessment is based on assuming that the electrode corrosion experienced during electrode feeding would not affect electrode length. Melt depth could also be monitored using operator-controlled electrode feeding, provided some determination is made of the amount of grip pressure required to lower the electrode to the bottom of the vitrified melt. As a third option, it may be desirable to measure melt depth, by "feeding" an electrically isolated graphite rod to the center of the ISV melt. This is particularly applicable for sites that have a high metals contents.

Data on the operating temperatures for the ES-INEL-3 test are Timited because of the failure of the Type $C$ thermocouple before the test was initiated. A second Type $C$ thermocouple that was inserted into the melt 19.3 hours after test startup showed a temperature of $1600^{\circ} \mathrm{C}$. As a result, it is expected that the operating temperatures were high enough to produce a high-quality vitrified product. 


\subsection{ELECTRODE PERFORMANCE}

The graphite electrode sections used for the ES-INEL-3 test were $5.1-\mathrm{cm}$ (2-in.)-diameter by 0.61-m (24-in.)-long grade MR from Superior Graphite Co. Each graphite section had male and female threaded ends for joining the sections. The electrodes were assembled by using a graphite joint paste to join the four sections. As supplied, the original joints consisted of a 1.9-cm (3/4-in.)-diameter threaded pin with a matching socket. During the initial set up and alignment of the electrode feed system, three of the joints broke because of the small pin design and a misaligned electrode gripper. Spare electrode sections were used in place of one of the broken joints and the other two joints were machined, making a larger and stronger $3.2-\mathrm{cm}$ (1-1/4-in.)-diameter threaded pin and socket. The electrodes were gripped as gently as possible during the actual test to prevent the other weaker joints from breaking.

To evaluate oxidation of the graphite electrode, which is commoniy observed immediately above the melt/air interface, the A-1 and B-1 electrodes were painted with four coats of a paint-on silicon carbide ( $\mathrm{SiC}$ ) coating. The A-2 and B-2 electrodes were left uncoated as a control. The SiC coating used is a Type SC manufactured by ZYP Coating Co. of Oak Ridge, Tennessee, and is intended for protecting graphite from air oxidation at temperatures up to $1000^{\circ} \mathrm{C}$. Silicon carbide coatings applied by the more expensive chemical vapor deposition (CVD) method were tested by PNL under a different study and were found to prevent air oxidation of graphite. In the same study, however, it was found that the CVD coating is wetted by the molten soil and can be corroded away if it is exposed long enough. For this reason, SiC-coated electrodes should be continualiy moved deeper into molten glass and should not be routinely retracted, since retraction could expose unprotected graphite to air.

The electrodes were visualiy monitored for oxidation during the test and their final dimensions were measured upon completion of the test. The most significant oxidation was observed on the uncoated electrodes, primarily electrode $A-2$. That electrode eventually failed so the test was discontinued. Data from visual observations of the A-2 electrode diameter as a function of 
run time are presented in Figure 5.6. Significant oxidation did not begin until after 7 hours of run time, which corresponds to the period of higher power input (see Figure 5.5). The reduction in the electrode's diameter was essentially linear after about 15 hours of run time. Figure 5.7 shows the extent of electrode oxidation present on the uncoated A-2 electrode during testing. 0xidation on the SiC-coated electrode was not visible until near the end of the test because the glass wetted and coated the SiC. Figure 5.7 shows the effect of the glass coating on the B-1 electrode.

Upon failure of the A-2 electrode and completion of the test, we attempted to remove the other electrodes. However, all of the electrodes broke off near the region of significant oxidation. Figure 5.8 shows the oxidized ends of the A-1, B-2, and A-2 electrodes. The B-1 electrode is not shown because it was broken in several places during removal. The A-1 electrode showed the least amount of oxidation and the location of the most

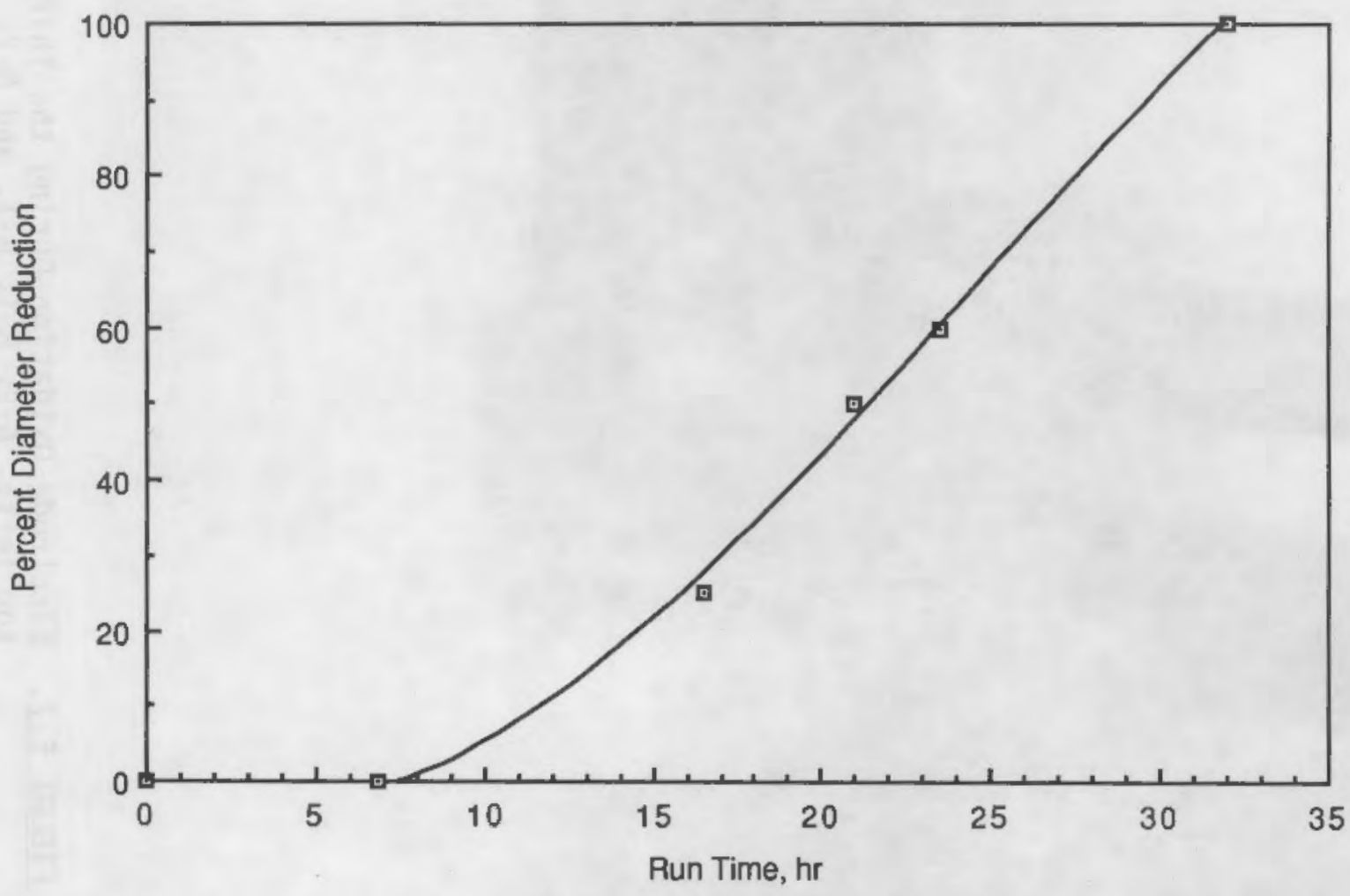

FIGURE 5.6. Reduced Diameter of Uncoated Electrode A-2 vs. Run Time 


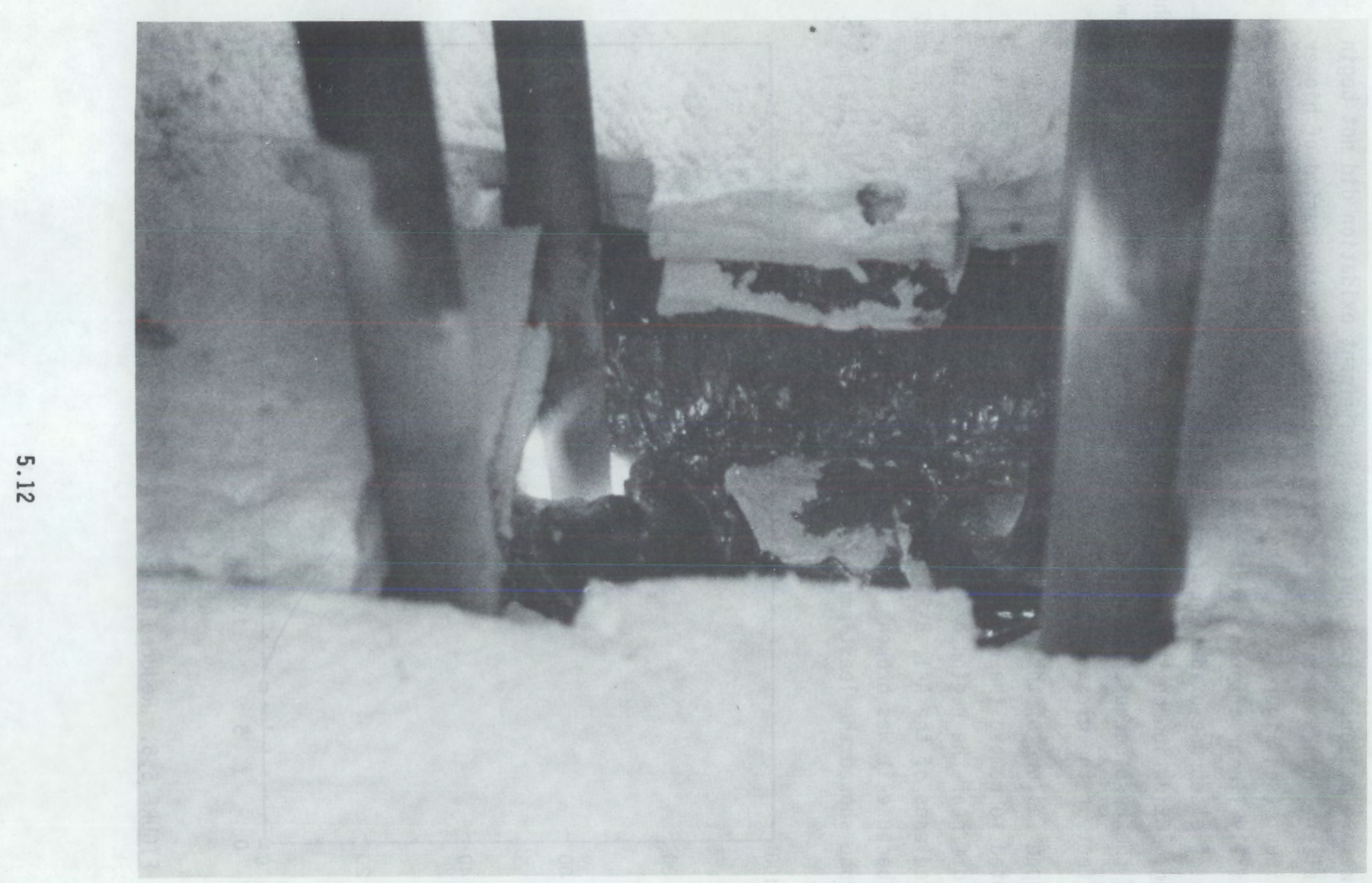

FIGURE 5.7. Electrode Oxidation During the Third ISV Engineering-Scale Test (clockwise from top left: $A-2, B-1, A-1$, and B-2; A-1 and B-1 are coated with SiC) 


$$
111
$$


significant electrode corrosion was 8 to $10 \mathrm{~cm}$ ( 3 to 4 in.) lower than that for the uncoated $A-2$ and $B-2$ electrodes. This indicates that the coating provided some additional protection against oxidation. The eventual failure of the SiC coating probably resulted from retracting and holding the electrodes above the melt bottom between 14.4 and 20.4 hours after test startup (refer to the electrode depth data shown in Figure 5.5). During this period, the melt subsidence level continued to move down the electrodes, exposing the electrode surface on which the protective coating had been corroded away by the molten soil. During normal ISV electrode feed operations, the electrodes would be continually lowered into the melt, leaving only the SiC-coated portion of the electrodes that had not been exposed to the corrosive molten soil. This technique should provide the electrodes with greater protection against oxidation.

Even with the oxidation that was observed, all four of the 5-cm (2-in.)diameter electrodes (coated and uncoated) permitted uninterrupted test operations for 32 hours. Assuming a direct correlation with electrode diameter, one would expect a life of nearly 100 hours for the electrodes during pilotscale operations in which $15-\mathrm{cm}\left(6-\right.$ in. $_{\text {. }}$-diameter, uncoated electrodes are used. If all four pilot-scale electrodes are coated, and if the electrodes are continuously fed without being withdrawn for extended periods of time, one would expect a significantly longer electrode life.

To evaluate the performance of the electrical contact shoes (see Figure 3.4), the direct current resistance between the contact shoes and the electrodes was measured several times during the test (with the power off). Figure 5.9 shows that the contact shoe resistances remained basically unchanged during the test, averaging only $0.22 \Omega$. At a maximum voltage of $400 \mathrm{~V}$, this results in an average power loss of only $88 \mathrm{~W}$ per contact shoe. The contacts were in good condition following the test and showed no signs of deterioration during engineering-scale testing. 


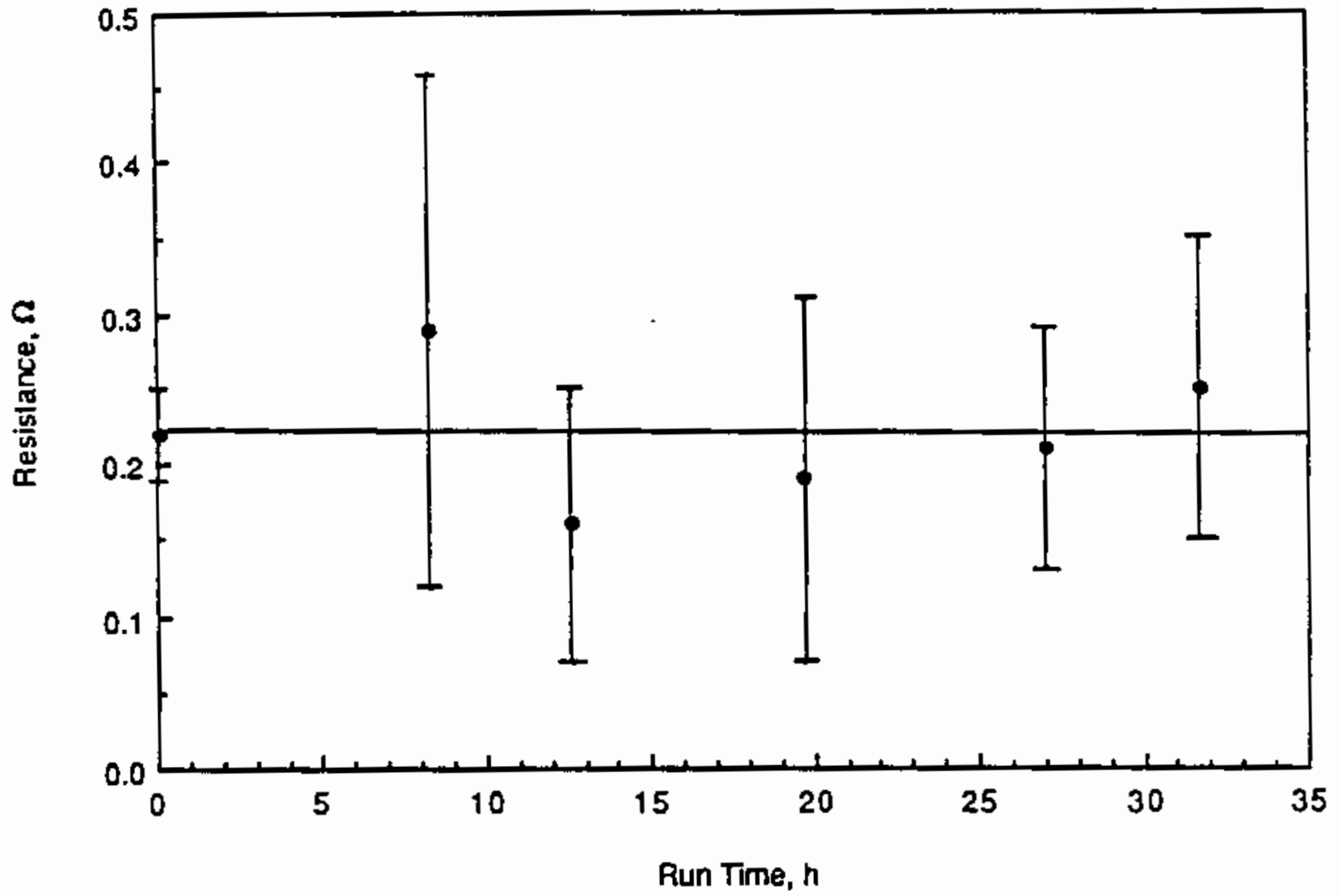

FIGURE 5.9. Contact Shoe Resistances as a Function of Run Time 
. 


\subsection{REFERENCES}

Buelt, J. L., and J. G. Carter. 19B6a. In Situ Vitrification Large-Scale Operational Acceptance Test Analysis. PNL-5828, Pacific Northwest Laboratory, Richland, Washington.

Buelt, J. L., and J. G. Carter. 1986b. Description and Capabilities of the Large-Scale In Situ Vitrification Process. PNL-5738, Pacific Northwest Laboratory, Richland, Washington.

Buelt, J. L., C. L. Timmerman, K. H. Oma, V. F. FitzPatrick, and J. G. Carter. 1987. In Situ Vitrification of Transuranic Waste: An Updated Systems Evaluation and Applications Assessment. PNL-4800, Supplement 1, Pacific Northwest Laboratory, Richland, Washington.

Carter, J. G., S. O. Bates, and G. D. Maupin. 1987. In Situ Vitrification of 0ak Ridge National Laboratory Soil and Limestone. PNL-6174, Pacific Northwest Laboratory, Richland, Washington.

Oma, K. H., D. R. Brown, J. L. Buelt, V. F. FitzPatrick, K. A. Hawley, G. B. Mellinger, B. A. Napier, D. J. Silviera, S. L. Stein, and C. L. Timmerman. 1983. In Situ Vitrification of Transuranic Wastes: Systems Evaluations and Applications Assessment. PNL-4800, Pacific Northwest Laboratory, Richland, Washington.

Oma, K. H., M. A. H. Reimus, and C. L. Timmerman. 1989. Support for the In Situ Vitrification Treatability Study at the Idaho National Engineering Laboratory: FY 1988 Summary. PNL-6787, Pacific Northwest Laboratory, Richland, Washington.

Timmerman, C. L., R. A. Brouns, J. L. Buelt, and K. H. Oma. 1983. "In Situ Vitrification: Pilot-Scale Development." Nuclear and Chemical Waste Management $4: 267$.

Timmerman, C. L., and K. H. Oma. 1984. An In Situ Vitrification Pilot-Scale Radioactive Test. PNL-5240, Pacific Northwest Laboratory, Richland, Washington. 
:

.

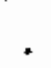




\section{DISTRIBUTION}

No. of

Copies

OFFSITE

12 DOE/Office of Scientific and Technical Information

T. B. Hindman, DP-12 DOE Office of Defense Programs GTN

Washington, DC 20545

H. F. Walter, EM-343

DOE Office of Waste Operations GTN

Washington, DC 20545

5 DOE Office of Environmental

Restoration and Waste Management

Forrestal Building

Washington, DC 20585

ATTN: C. R. Cooley, EM-55

T. D. Anderson, EM-442

C. Frank, EM-50

S. Prestwich, EM-52

S. P. Mathur, EM-54

J. Arthur

DOE Albuquerque Operations

Office

P.0. Box 5400

Albuquerque, NM 87185

E. Maestas

DOE West Valley Project

P.0. Box 191

West Valley, NY 14171

3 DOE Idaho Operations office

785 DOE Place

Idaho Falls, ID 83402

ATTN: J. P. Hamric

M. W. Shupe

S. A. Morreale
No. of

Copies

W. T. Goldston

DOE Savannah River Operations Office

P.0. Box A

Aiken, SC 29801

K. H. Oma

Eckenfelder Inc.

227 French Landing Drive

Nashville, TN 37228

M. J. Steindler, CMT-205

Argonne National Laboratory

9700 South Cass Avenue

Argonne, IL 60439

3 Battelle Memorial Institute

$505 \mathrm{King}$ Avenue

Columbus, $\mathrm{OH} 43201$

ATTN: W. A. Carbeiner

R. A. Nathan

Technical Library

L. D. Ramspott, L209

Lawrence Livermore National Laboratory

University of California

P.0. Box 808

Livermore, CA 94550

M.A.H. Reimus

Los ATamos National Laboratory

P.0. Box 1663

Los Alamos, NM 87545

4 Oak Ridge Nationa] Laboratory

P.0. Box $Y$

0ak Ridge, TN 37830

ATTN: G. K. Jacobs

L. J. Mezga

T. A. Row

B. P. Spalding 
No. of

Copies

2 Sandia Laboratories

P.0. Box 5800

Albuquerque, NM 87185

ATTN: R. W. Lynch

Technical Library

12 EG\&G Idaho

P.0. Box 1625

Idaho Falls, ID 83415

ATTN: S. 0. Bates

B. L. Charboneau (5)

T. L. Clements

J. L. Landon

D. Nickel son

R. H. Schletter

N. Smith

J. R. Weidner

J. R. Berreth

Westinghouse Idaho Nuclear

Co., Inc.

P.0. Box 4000

Idaho Falls, ID 83401

5 Westinghouse Savannah River Company

Aiken, SC 29801

ATTN: R. G. Baxter

J. Haselow

C. M. Jantzen

M. J. Plodinec

J. Steele

J. M. Pope

West Valley Nuclear

Services Co.

P.0. Box 191

West Valley, NY 14171

3 Geosafe Corporation

KirkTand Park Place

303 Park Place, Suite 126

Kirkland, WA 98033

ATTN: V. F. FitzPatrick

C. L. Timmerman

J. G. Carter
No. of

Copies

ONSITE

8 DOE Richland Operations Office

E. A. Bracken, A6-95

G. J. Bracken, A6-80

P. K. Clark, A6-80

P. F. Dunigan, A6-95

M. J. Furman, $A 6-80$

R. E. Gerton, $A 6-80$

R. D. Izatt, $A 6-95$

J. J. Sutey, A5-90

10 Westinghouse Hanford Company

J. W. Cammann, H4-54

K. R. Fecht, H4-56

R. E. Lerch, B2-35

H. E. McGuire, B2-35

J. L. Scott, R2-87

J. C. Sonnichsen, H4-54

D. A. Turner, R1-10

D. D. Wodrich, R1-48

R. D. Wojtasek, B2-15

B. A. Wolfe, L5-6l

40 Pacific Northwest Laboratory

C. E. Bigelow, P7-44

W. F. Bonner, P7-44

T. H. Brouns, P7-44

J. L. Buelt, P7-44

H. C. Burkholder, P7-41

B. E. Campbel1, P7-44

C. C. Chapman, P7-41

T. T. Claudson, Kl-66

R. K. Farnsworth, (10) P7-44

R. D. Gibby, P7-44

W. 0. Heath, P7-44

C. H. Kindle, (3) P7-44

D. E. Knowlton, P7-40

S. S. KoegTer, P7-44

W. L. Kuhn, P7-14

J. L. McElroy, P7-46

K. A. Parne11, P7-14

M. E. Peterson, P7-44 
No. of

Copies

Pacific Northwest Laboratory (contd)

T. D. Powe17, P7-44

J. W. Shade, P8-37

C. M. Smith, P7-43

J. A. Stott lemyre, K6-78

L. E. Thompson, P7-44

Publishing Coordination

Technical Report Files (5) 
